ICIP WORKING PAPERS:

2010/09

The Security Council and the Legitimacy of the Use of Force: Legal, Normative and Social Aspects

Matilde Pérez Herranz 


\section{The Security Council and the Legitimacy of the Use of Force: Legal, Normative, and Social Aspects}

Matilde Pérez Herranz

Institut Català Internacional per la Pau Barcelona, December 2010 
Gran Via de les Corts Catalanes 658, baixos · o8010 Barcelona

T. +349355442 70 | F. +34935544280

recerca.icip@gencat.cat|http://www.icip.cat

\section{Editors}

Javier Alcalde and Rafael Grasa

\section{Editorial Board}

Pablo Aguiar, Alfons Barceló, Catherine Charrett, Gemma Collantes-Celador, Caterina Garcia, Abel Escribà, Vicenç Fisas, Tica Font, Antoni Pigrau, Xavier Pons, Alejandro Pozo, Mònica Sabata, Jaume Saura, Antoni Segura and Josep Maria Terricabras

\section{Text Correction}

Charles Southgate

\section{Graphic Design}

Fundació Tam-Tam

\section{ISSN}

2013-5793 (edición en línea)

2013-5785 (edición en papel)

\section{DL}

B-38.039-2009

(C) 2010 Institut Català Internacional per la Pau

All rights reserved 


\section{THE AUTHOR}

Matilde Pérez Herranz is Lecturer in International Relations at the Department of International Law and International Relations at the Universitat Pompeu Fabra. She graduated in Law and Political Science and Public Administration and she holds an MA in International Studies from the Universidad Autónoma of Madrid. She has been visiting researcher at the Maison Française d'Oxford/ Centre National de la Recherche Scientifique in Oxford, and at the International Peace Research Institute in Oslo. Her main research areas are International Relations Theory, discourse analysis and armed conflict. She currently works on her doctoral research focused on the analysis of the concept of international legitimacy and its application to the use of force.

\section{ABSTRACT}

It is well known that the Security Council bears the primary responsibility for the maintenance of international peace and security. According to the Charter of the United Nations, the Security Council determines the existence of any threat to the peace, breach of peace or act of aggression, and it decides what measures, involving the use of armed force, are to be employed to restore peace and security. The aim of this paper is to explore the concept of legitimacy as applied to the use of force in international relations and its evolution over the past two decades. To this end, the paper first looks at a complex definition of legitimate use of force focusing on its legal, normative and social dimensions. It then goes on to analyse how these three dimensions are represented in the debates of the Security Council on the war in Iraq, one of the most controversial and equivocal uses of force in recent years. The analysis enables certain conclusions to be drawn on the changing foundations of legitimacy with regard to the use of force, as well as the dominant tensions that surround it.

Keywords: United Nations. Security Council, War on terrorism, Just war doctrine, Preemptive attack, Intervention, Self-defense 


\section{RESUM}

Tal i com estableix la Carta de les Nacions Unides, el Consell de Seguretat determina l'existència d'una amenaça a la pau, un trencament de la pau o un acte d'agressió i decideix les mesures que han de fer-se servir per restaurar la pau i seguretat internacionals, també l'ús de la força. L'objectiu d'aquest article és explorar la legitimitat d'aquest ús de la força. Amb aquest objectiu, el text parteix d'una definició centrada en les seves dimensions legal, normativa i social. En segon lloc, s'analitzarà com aquestes dimensions estan representades als debats del Consell de Seguretat de la guerra d'Irak de 2003, un dels usos de la força més controvertits i que més debat ha generat als darrers anys. Finalment, l'anàlisi proposat permet treure algunes conclusions sobre les bases canviants de la legitimitat de l'ús de la força.

Paraules clau: Naciones Unidas. Consejo de Seguridad, Guerra contra el terrorismo, Ataques preventivos, Intervenciones, Legítima defensa

\section{RESUMEN}

Según establece la Carta de las Naciones Unidas, el Consejo de Seguridad determina la existencia de una amenaza a la paz, un quebrantamiento de la paz o un acto de agresión y decide las medidas que han de emplearse para restaurar la paz y seguridad internacionales, incluido el uso de la fuerza. El objetivo de este artículo es explorar la legitimidad de este uso de la fuerza. Con tal fin, este trabajo parte de una definición centrada en sus dimensiones legal, normativa y social para analizar cómo estas dimensiones están representadas en los debates del Consejo de Seguridad de la guerra de Irak de 2003, uno de los usos de la fuerza más controvertidos y que más debate ha generado en los últimos años. Finalmente, el análisis propuesto permite extraer algunas conclusiones acerca de las bases cambiantes de la legitimidad del uso de la fuerza.

Palabras clave: Naciones Unidas. Consejo de Seguridad, Guerra contra el terrorismo, Ataques preventivos, Intervenciones, Legítima defensa 


\section{CONTENTS}

1. INTRODUCTION

2. LEGITIMACY OF THE USE OF FORCE:

A MULTI-DIMENSIONAL APPROACH 9

2.1. THE LEGAL DIMENSION OF THE LEGITIMATEUSE OF FORCE 12

2.2. THE NORMATIVE DIMENSION OF THE LEGITIMATE USE OF FORCE 16

2.3. THE SOCIAL DIMENSION OF THE LEGITIMATE USE OF FORCE 21

3. THE LEGAL, NORMATIVE AND SOCIAL DIMENSIONS

OF THE LEGITIMATE USE OF FORCE IN THE DEBATES

ON THE IRAQ WAR OF 2003

3.1. THE LEGAL DIMENSION OF THE LEGITIMATE USE OF FORCE IN THE DEBATES ON THE IRAQ WAR OF 2003

3.2. THE NORMATIVE DIMENSION OF THE LEGITIMATE USE OF FORCE IN THE DEBATES ON THE IRAQ WAR OF 2003

3.3. THE SOCIAL DIMENSION OF THE LEGITIMATE USE OF FORCE IN THE DEBATES ON THE IRAQ WAR OF 2003 



\section{INTRODUCTION*}

It is well known that the United Nations Security Council (UNSC) holds responsibility for maintaining international peace and security. As defined by the United Nations Charter, the UNSC shall decide on the existence of a threat to peace, a breach of peace or an act of aggression, and it will decide on the measures to be taken to restore international peace and security, including the use of force.

The objective of this paper is to explore the legitimacy of the use of force. It puts forward a complex conception of legitimacy that allows the full meaning of legitimate use of force to be understood. In order to achieve its objective, the paper starts out with the concept of legitimacy formulated by David Beetham, according to which legitimacy is a multi-dimensional concept that comprises legal, normative and social aspects. This multi-dimensional concept considers the use of force to be legitimate when it is in accord with the principles laid down in the UN Charter, i.e. when it is used to maintain international peace and security and that it has UNSC authorisation.

Given the abovementioned objective, the paper sets out to analyse the arguments for and against the use of force from a series of UNSC debates which took place with reference to the Iraq War in 2003, one of the most controversial cases the UNSC has had to deal with and that which has generated more debate than any other in recent years. A starting premise is the important connection between debate and legitimacy. As Andrew Hurrell has pointed out, "Legitimacy is about providing persuasive reasons as to why a course of action, a rule, or a political order is right and appropriate" (Hurrell, 2005, 24). In this paper, and for this purpose, debate is conceived of as a social process, i.e. not only does it reflect certain facts and events, but that the action of debating itself brings with it an interpretation

* The author would like to thank Caterina García Segura, Pablo Pareja Alcaraz, Daniel Nicholls and an anonymous reviewer for their valuable comments and suggestions. 
of, and a construct for, such facts and events, social relations and the subjects that participate in them (Martín Rojo, Pardo, and Whittaker, 1998, 12).

Unlike resolutions, which are documents of consensus resulting, in large part, from the use of ambiguous language, the transcripts of the debates provide access to the dialectical exchanges between the members of the UNSC, the one body considered to be the legitimate authority to authorise the use of force. In specific terms, the analysis here focuses on the speeches by the five permanent members in five UNSC debates. Three of these took place prior to military operations (S/PV. 4701, 5 February 2003; S/PV. 4714, 7 March 2003; and S/PV. 4721, 19 March 2003), one during the operations (S/PV. 4726, 26 March 2003) and another subsequent to the formal declaration of the cessation of operations (S/PV. 4791, 22 July 2003). With the start of military operations being established as the key moment in time, these debates were chosen because of the particularly intense and vehement arguing that took place.

The analysis of the arguments used by the proponents and opponents of the use of force in the case of Iraq leads to two final points. Firstly, the importance of a multi-dimensional conception for understanding the complexity of the legitimate use of force in international relations. Study of the UNSC debates shows how the members resorted to legal, normative and social arguments to support the legitimacy of their positions, whether they were in favour of or against the use of force in Iraq. Secondly, by applying Neta Crawford's concept of social change through discourse, we can see how it is possible to prove that there was a challenge to, and an attempt to reformulate, the grounds for the legitimate use of force by the leaders of the coalition. According to Crawford, social change is a process defined through a series of phases of discourse, the objective of which is to modify and reconstruct the prevailing ideas, and then promote political and institutional change in line with the newly established ideas. Phase one, or denormalisation, is the calling into question of dominant practices that are considered to be normal and correct. Phase two, or delegitimation, is where ar- 
guments are used to alter perceptions of legitimacy associated with a certain practice, the aim being to demonstrate that there is no connection between behaviour and the existing normative beliefs. Phase three sees deconstruction of the existing discourse, thereby allowing for the appearance and expression of new beliefs and arguments. This is followed by a phase of reconstruction, which is based on creating the sensation that it is possible to adapt behaviour in line with new guidelines. In addition, it is necessary to ensure that the interests of the actors are reformulated in accordance with this new discourse. The final phase, known as institutionalisation, takes place when the new arguments have persuaded a sufficient number of people that the previously predominant practice is alien, strange and illegitimate. Thus, by means of a new consensus, new normative standards become incorporated into the practices of international actors (Crawford, 2002).

This paper is structured into three main parts. The first analyses the multi-dimensional concept of legitimacy and its application to the use of force. The second part studies the way in which the three dimensions of the use of force appear in the discourse used by the proponents and opponents of the use of force against Iraq in 2003. The last section examines the implications of the case study for the conception of the legitimate use of force and analyses the effects of social change on the norms that regulate the use of force.

\section{LEGITIMACY OF THE USE OF FORCE: A MULTI-DIMENSIONAL APPROACH}

The approach to the legitimacy of the use of force set out in this paper is based on the model developed by David Beetham in his work The Legitimation of Power, in which he conceives legitimacy not as a quality that can be assigned but rather as a complex equilibrium be- 
tween various components. ${ }^{1}$ Breaking away from Weber's conception of legitimacy and the immense influence it has had ever since it was formulated, ${ }^{2}$ Beetham disputes the subjective psychological aspect of the belief in legitimacy. He lays particular emphasis on the great confusion stemming from the acceptance of this interpretation in the social sciences and explains that the problem with Weber's definition is twofold. Firstly, it distorts the relation between beliefs and legitimacy. Beetham argues that a power relationship is assumed to be legitimate not simply because the parties subject to it believe it to be so, but rather because it is consistent with their belief system, which is to say that it can be justified in terms of their beliefs, values or normative expectations. What is important for the analysis of legitimacy is the existence or otherwise of discrepancies between rules and the values or beliefs that underlie them (Beetham, 1991, 12). Andrew Hurrell argues along similar lines in stating that "legitimacy is not simply what people tend to accept in the sociological sense; it is what people accept because of some normative understanding or process of persuasion. Justifying and reason-giving are fundamental" (Hurrell, 2005, 16). Secondly, Weber's definition of legitimacy does not take into account

1. Academic interest in legitimacy as a fundamental concept within international relations theory is widespread, especially amongst constructivist authors, although the concept has not generally been analysed in any real depth. One honourable exception to this is the comprehensive study by Ian Clark in his book Legitimacy in International Society, in which he posits that international legitimacy cannot be reduced to any one institution, norm or set of values, but depicts "depicts a highly volatile condition of political balance amongst the diverse elements that seek to capture it." See Legitimacy in International Society, Oxford University Press, 2005, p. 159.

2. Weber distinguishes between power ("the probability that one actor [...] will be in a position to carry out his own will") and domination ("the probability that a command with a given specific content will be obeyed by a given group of persons"). The key to creating this obedience resides in those who are dominated recognising the authority of those who dominate them. That is, the dominated must believe in the legitimacy of the dominant. Consequently, the nature of the reasons that lead to a command being obeyed will determine the type of legitimate domination that is generated. Weber thus presents three ideal types of legitimate domination: rational, based in legality as the principal source of legitimacy; traditional, in which tradition grants authority to those who have always exercised it; and charismatic, which rests on certain personal attributes of those who exercise domination. See Weber, M. (1944) Economy and society (originally published in German, 1922), p. 53. 
aspects that are unrelated to beliefs, such as the fact that power is exercised in accordance with legality, or that the consent of those affected by the exercise of power is expressed through different actions.

With the aim of transcending the Weberian concept of legitimacy, Beetham sets out a complex concept that seeks to deal with certain theoretical issues across various different disciplines. From the perspective of Law, for example, legitimacy has been conceived to be equivalent to legality; in Philosophy, it has been understood to mean the justifiability of rules in accordance with moral norms; and in the Social Sciences, legitimacy has been interpreted according to Weber's model, i.e. as the belief in the appropriateness of the political system by prominent social actors. According to Beetham's analysis, legitimacy is not a quality that political systems either possess or lack, but a set of criteria or dimensions that provide the basis for the conformity or cooperation of the subordinate party in the power relationship (Beetham, 1991, 20). It is important to point out that these are general criteria that give an overall picture of the study of legitimacy in different places and at different times. Needless to say, any analysis of multi-dimensional legitimacy should be carried out according to the specific context of each case and will thus vary over time (Beetham, 1991, 21).

The first dimension or criterion of legitimacy studied by Beetham is conformity with the rules, or legality. A source of authority will thus be legitimate when its behaviour conforms to the established rules. The existence of rules, whether in the form of codified or customary laws, is a fundamental social element as it allows the actors to create expectations about the behaviour of others. It is interesting to note that the more a law is resorted to as a source of legitimacy, the more necessary it becomes for the law be complied with for its legitimacy to be maintained. According to Beetham, this dimension alone is not enough to explain why a source of authority is legitimate. The criterion of legality cannot be sufficient in itself, and the fact that one set of rules is considered as the basis for the legitimate exercise of power and not another is because of its normative content, which Beetham examines in his second dimension.

In this second dimension, Beetham sees legitimacy as the justifiability of the rules, i.e. rules must refer to a common scheme of beliefs or 
norms. Justification can come from: a) the rightful source of authority from which the rules stem, either external to the society in which it exists - such as divine will, natural law or scientific doctrines - or internal, such as tradition or the popular will; or b) the content of the rules being justified either by the principle of differentiation between the capabilities of the dominant and subordinate groups or by appeal to the common interest shared by these two groups (Beetham, 1991, pp. 69 et seq.).

In the third dimension, legitimacy is expressed through consent. What is important about this dimension is the form or actions through which this consent is expressed, as it is these actions that confer legitimacy on those who govern. In this way subordinates confirm either their express consent within the power relationship or their voluntary agreement to limit their liberty in accordance with what has been established by the powerful (Beetham, 1991, 91). There are various ways in which this consent can be granted, though, according to Beetham, in the modern world, given the widespread acceptance of the principle of popular sovereignty, political legitimation must wide-ranging. One fundamental requirement is that everyone is able to express their consent and that this takes place through an electoral process or political mobilisation that demonstrates popular support.

The application of Beetham's model to the study of the legitimacy of the use of force enables three fundamental dimensions - legal, normative and social - to be defined. The concepts of legality, morality and authority are thus also included here in this analysis of the use of force in order to clarify this key concept, the full complexity of which may be difficult to grasp. The analysis provides food for thought regarding the legitimate use of force in terms of the norms that govern it, the values that these norms seek to protect, and the issue of who actually holds the authority to authorise the use of force in international relations.

\subsection{THE LEGAL DIMENSION OF THE LEGITIMATE USE OF FORCE}

The legal dimension of the legitimate use of force is composed of the legal framework that is applicable to this matter. According to this di- 
mension, in order for the use of force in international relations to be legitimate it must comply with the norms that regulate its use. The UN Charter constitutes the prevailing normative framework that governs the use of force (Casanovas y La Rosa, 2007, 1038).

The Preamble to the Charter sets out the fundamental purpose of the organisation, which is to maintain international peace and security. With the aim of achieving this objective, the first chapter specifies a series of common aims and principles or guidelines for action, the fundamental purpose of which is the maintenance of international peace and security (Art. 1.1). The general prohibition of the use of force can be considered as the starting point for the Charter's system for the maintenance of international peace and security (Art. 2.4). According to Robert Kolb, the system created in the Charter contains two parts: the preventive part dedicated to the peaceful settlement of disputes (Ch. VI) and economic and social cooperation (Ch. X); and a repressive part that regulates the coercive powers of the UNSC (Ch. VII) (Kolb, 2003, 51).

The maintenance of international peace and security rests fundamentally with the Security Council and the General Assembly. The UNSC is the organisation that holds the primary responsibility for this and must carry out its duties in this respect in accordance with the aims and principles of the United Nations (Art. 24.2). This is set out in Article 24.1 of the Charter, which justifies this responsibility being conferred on the UNSC in order to "ensure prompt and effective action” (Cardona Llorens, 2003, 219).

The principal exceptions to the general prohibition of the use of force are the right to legitimate self-defence and the collective security system. ${ }^{3}$

3. Together with the exceptions mentioned, Ch. VIII of the Charter covers actions carried out by regional organisations with jurisdiction to deal with international peace and security. Where coercive actions are concerned, Art. 53.1 establishes a relationship of subordination with regional organisations in two ways: firstly, the UNSC can utilise these arrangements or agencies to apply coercive measures under its authority; and, secondly, the UNSC has to authorise the coercive measures it wishes to implement in terms of these regional arrangements or agencies. Furthermore, there are other exceptions to the prohibition of the use of force that are questioned according to doctrine. In this respect, particular note is made of the following cases: humanitarian intervention, the use of force within the framework of decolonisation on the part of national liberation movements, the use of force to protect nationals abroad and responses to uses of force which are distinct from an armed attack. 
The first of these exceptions is set out in Article 51, which establishes the characteristics of the right of legitimate self-defence (imminent, individual or collective), the enabling factor (armed attack) and the conditions under which it must be carried out (its provisional nature and subsidiarity with respect to the collective security system). To these, three additional conditions deriving from general international law must be added, namely immediacy, necessity and proportionality.

One particularly thorny issue is that of the pre-emptive or preventive use of this right. Pre-emptive use of force is aimed at stopping an imminent attack by a hostile state, whilst preventive use of force is designed to prevent a hostile state from creating the capabilities to attack (Espósito, 2005). Although the pre-emptive use of force could be understood to fall within the legitimate right to self-defence, the case of preventive self-defence is different. As Neta Crawford points out, a pre-emptive act comes dangerously close to being a preventive act if a series of conditions are not met (Crawford, 2003, 30-36). First, the object of preemptive self-defence by a state must be as narrowly confined as possible to immediate risks to life and health within borders or to the life and health of citizens abroad. Second, there would have to be strong evidence that war was inevitable and likely in the immediate future - within days or weeks - thus highlighting the key role of clear intelligence. Thirdly, pre-emption should be likely to succeed in reducing the threat. Lastly, military force must be necessary. ${ }^{4}$

The second exception to the prohibition of the use of force is the collective security system laid out in Chapter VII of the UN Charter. The Security Council is responsible for determining the existence of threats to peace, breaches of peace or acts of aggression, which vary from vague threats through to specific acts of aggression (Art. 39). Once the situation has been categorised as one of these types, the UNSC has pow-

4. On 5 August 2005, the UN Secretary-General cast light on this issue in the report In larger freedom: towards development, security and human rights for all by establishing that the response to imminent threats is covered by the right to legitimate defence (see paragraph 124). In the case of latent threats, the report establishes that "the Charter gives full authority to the Security Council to use military force, including preventively, to preserve international peace and security."(See paragraph 125). The preventive use of force is thus reserved as a competence of the Security Council. 
ers to make recommendations or decisions to maintain or re-establish the peace. Furthermore, the UNSC can dictate provisional measures to prevent the situation from worsening, such as a ceasefire, the withdrawal of troops, a truce or an armistice, amongst others (Art. 40). In order to maintain or re-establish international peace and security the UNSC can take measures that do not involve the use of armed force, but which impact on the economic situation, transport and communications, or diplomatic relations (Art. 41). If these measures are considered inadequate or fail to bring about the desired effect, the UNSC "may take such action by air, sea, or land forces as may be necessary to maintain or restore international peace and security. Such action may include demonstrations, blockade, and other operations by air, sea, or land forces of Members of the United Nations" (Art. 42).

It is important to stress that whilst the measures decreed within the remit of Article 41 are legally binding on member States, the military measures of Article 42 are linked to the signing of special agreements through which the signatory States place at the disposal of the UNSC "armed forces, assistance, and facilities, including rights of passage, necessary for the purpose of maintaining international peace and security" (Art. 43). These agreements have never actually been signed, meaning that the system of collective security provided for in the Charter has never been implemented. The UNSC has thus created alternative channels of action, provided for in the Charter or otherwise, in order to carry out coercive measures. Firstly, use is made of regional arrangements or agencies in order to apply coercive measures under the UN's authority (Art. 53). Second, the UNSC has authorised member States to use force to guarantee that embargoes are respected or to re-establish international peace and security. Third, it has used the authorisation of peacekeeping operations and of multinational forces carrying out equivalent functions to defend its mandate (Cardona Llorens, 2005, 317-342).

The authorisation of the use of force by the UNSC must fulfil five requisites in order to be legal (Corten, 2008; Lagrange, 2004). Firstly, the UN must pass a resolution authorising coercive action by a multinational force. As Olivier Corten points out, UNSC authorisations 
resorting to the use of force can be explicit, when specific measures are detailed in the text of the resolution itself, or implicit, when the resolution resorts to the customary formula of "all necessary means". This latter method of authorisation has been the one most used by the UNSC. ${ }^{5}$ Secondly, any resolution that is passed must comply with the Charter, both in its form and content. Thirdly, any military action must be in accordance with the UNSC resolution. Olivier Corten states that, in practice, the UNSC has resorted to the criterion of necessity, although prescribing the "use of all means necessary" does not represent the unconditional and unlimited right to use military force (Corten, 2008, 507). Given that actual cases of authorisation have been highly varied, their classification is difficult. Interpretation must be done on a case-by-case basis and the transcripts of the debates reviewed in order to be certain that the use of force is understood to be included in the resolution. Fourthly, both financing and the command of operations are independent of the UN. The cost of the operation is to be met by the participating states, including voluntary contributions from other states which are unable or unwilling to get involved on the ground. The operations are to be carried out by a multinational force, i.e. an aggregation of national forces each operating under its own flag. Fifth, the UNSC must stay in control of the authorised action. In general terms, the means of control used by the UNSC for any authorised action include the obligatory submission of written reports from the states involved, the state commanding the operation or the Secretary-General.

\subsection{THE NORMATIVE DIMENSION OF THE LEGITIMATE USE OF FORCE}

The normative dimension of the legitimate use of force refers to the justification of the norms that govern the use of force in terms of shared values or beliefs. The legitimacy of the legal system governing

5. During the Cold War the UNSC used recommendation instead of authorisation (which is more commanding). 
the use of force will, in normative terms, thus derive from common values which it seeks to protect, namely, the maintenance of international peace and security. Following the demise of the pervasive bipolar logic of the Cold War, the interpretation of what constitutes a threat to international peace and security was widened considerably. Humanitarian issues were first incorporated, followed by the proliferation of weapons of mass destruction and terrorism as new threats after the $9 / 11$ attacks.

Following the fall of the Berlin Wall, the international panorama was one of uncertainty. George Bush, in a speech to Congress, referred to a new order that "is struggling to be born, a world quite different from the one we've known. A world where the rule of law supplants the rule of the jungle. A world in which nations recognise the shared responsibility for freedom and justice. A world where the strong respect the rights of the weak."6

Within this context, in which the international order was being redefined, the proliferation of a new type of armed conflict - dubbed "new wars" by Mary Kaldor ${ }^{7}$ and extensively covered by the global media saw the need for action against serious violations of human rights push its way to the top of the international agenda. Justification for the use of military force was linked to this issue through the development of humanitarian intervention and peace-building and peace-keeping operations. The UN did in fact lead numerous conflict-prevention initiatives, peace-keeping and peace-building operations, as well as post-conflict

6. Speech by George Bush to the US Congress, 11 September 1990. Document available at: http://bushlibrary.tamu.edu/research/papers/1990/90091101.html

7. According to Mary Kaldor, the main differences between traditional armed conflicts and new wars can be summed up in three fundamental aspects. First, the objectives are linked to the political objectives of specific identity groups. Second, the conflict methods deployed in the new wars are inspired by guerrilla warfare carried out by irregular armed forces, mercenaries and paramilitary forces with a decentralised operations system. In addition, in line with identity politics, other identity groups are displaced or even annihilated through ethnic cleansing, among other methods. Third, these wars are financed by a "globalised" war economy that feeds off illegal trade, the seizing of humanitarian aid, and foreign support, either from neighbouring countries or diasporas. See Kaldor, M. (2007) New and Old Wars. Organized violence in a global era. Stanford University Press, pp. 7-10. (Second ed.). 
reconstruction programmes. ${ }^{8}$ It was increasingly being accepted that the international community had a legitimate interest in what was happening in different countries. Coupled with this interest was the erosion of sovereignty - the guiding principle of the international order - which had now become a right that "had to be earned".

The proliferation during the 1990 s of cases in which the use of force was justified on humanitarian grounds, in the main multilateral interventions and within the framework of peacekeeping operations, showed how the concept of a threat to international peace and security was widening and how these questions were being incorporated into the normative dimension of the legitimate use of force. ${ }^{9}$ Although the majority of interventions involving the use of force on humanitarian grounds were carried out under the authorisation or supervision of the UN, the case of the NATO intervention in Kosovo in 1999, which took place without UNSC authorisation, had important repercussions as it opened up a breach between legality and legitimacy (Wheeler, 2000). In October 2000 the Kosovo Report: Conflict, International Response, Lessons Learned was published. It was produced by the International Independent Commission for Kosovo, whose principal conclusion was that the NATO military intervention in Kosovo was illegal, as it was not backed by UNSC authorisation, yet legitimate, as diplomatic efforts at a solution had been exhausted and the two parts were locked into a conflict which would end in a humanitarian massacre and generate serious instability in the Balkans. As a consequence, the case of Kosovo set an important, yet limited, precedent as it could only be invoked in cases with the two following circumstances: where

8. According to the Human Security Report 2005, the number of preventive diplomatic missions increased six-fold in the period 1990-2002; peace-promotion activities increased fourfold during the same period; peace-building activities promoted by governments through initiatives such as contact groups and Friends of the Secretary-General grew by up to seven times in the period 1990-2003; economic sanctions underwent spectacular growth and increased eleven-fold over the period 1989-2001; finally, between 1987 and 1999, UN peacekeeping operations quadrupled. See Human Security Centre (2005) Human Security Report 2005: War and Peace in the 21st Century. New York: Oxford University Press.

9. Especially noteworthy are the actions in the north of Iraq, Bosnia, Somalia, Haiti, Rwanda, Kosovo and East Timor. 
the UNSC, on identifying human rights abuses carried out by a government as a threat to peace and security, adopts Chapter VII measures; and where the UNSC is deadlocked either by the threat or use of the veto (Wheeler, 2002, 293). As Itziar Ruiz-Giménez points out, this case demonstrates that humanitarian issues had penetrated the international normative structure and that they thus constituted justifications for the use of force. In the case of Kosovo, the question was no longer whether or not there was a humanitarian crisis nor whether or not this was a threat to peace and security because in the UNSC debates there was already consensus that this was in fact the case. The divergence lay in the procedure to follow in order to respond to the crisis, given that the NATO intervention was illegal. In order to be legitimate, any military intervention would have to be multilateral and approved by the UNSC (Ruiz-Giménez, 2005, 241-245).

After a ten-year period distinguished by the development of humanitarian interventions, there began a global reformulation of the dilemma over what the international community should do in the face of mass violations of human rights. Whilst the view in the nineties was that humanitarian intervention was a right from the point of view of the state, by the early twenty-first century the terms of analysis had changed, with the focus being placed on those who suffer the effects of human rights abuses - the people that the state and the international community had a responsibility to protect. In 2001 the report of the International Commission on Intervention and State Sovereignty entitled The Responsibility to Protect was published. This document specified a new conception of state sovereignty, which had been conceived and developed during the nineties, namely, responsible sovereignty. Sovereignty was thus no longer a right in itself, but one which implied being responsible for the suffering endured by the state's own citizens and others.

The principle of the responsibility to protect was later included in two important documents. In the report by the Secretary-General's High-Level Panel on Threats, Challenges and Change, A More Secure World: Our Shared Responsibility, published in 2004 and drawn up at the request of the UN Secretary-General, Kofi Annan, a new vision of collective security for the twenty-first century was set out. Within this 
new approach, and in pursuit of the emerging norm of a collective international responsibility to protect, the authors of the report acknowledge that the Security Council can exercise this norm by "authorizing military intervention as a last resort, in the event of genocide and other large-scale killing, ethnic cleansing or serious violations of international humanitarian law which sovereign governments have proved powerless or unwilling to prevent" (A/59/2005, paragraph 203). This document also includes a request for the individual permanent members of the UNSC to pledge themselves to refrain from using the right to veto in cases of genocide and large-scale abuses of human rights (A/59/565, 256). In the same vein, the Secretary-General's Report of 2005, In Larger Freedom, states that "we must embrace the responsibility to protect and, when necessary, we must act on it" (A/59/2005, $39)$. Both reports stress that, in cases where the use of force is necessary, the responsibility shall fall exclusively on the Security Council.

The assumption of the responsibility to protect sought to create consensus around intervention for humanitarian reasons by proposing a series of requirements to be met when carrying out a military intervention. ${ }^{10}$ It was thought that, by making states commit explicitly to complying with a series of norms when using force, it would be more difficult to resort to more dubious humanitarian reasons to justify an intervention. The adoption of this principle by the General Assembly in the formal declaration of the 2005 World Summit has contributed to establishing this rule, though its implementation continues to be conditioned by the acceptance of the permanent members of the Security Council.

Whilst the 1990 s were distinguished by the incorporation of humanitarian justifications into the normative dimension of the legitimate use of force, the terrorist attacks of 11 September 2001 inaugurated a decade in which international terrorism and weapons of mass destruction would come to the forefront as the principal threats to international peace and security. Unlike the majority of humanitarian interventions

10. These requirements are basically a reformulation of Just War theory. See International Commission on Intervention and State Sovereignty (2001) The Responsibility to Protect, pp. XII and XIII. Document available at: http://www.iciss.ca/report-en.asp 
in the nineties, the use of force in dealing with these new threats has shifted away from multilateralism and become contextualised within the unilateral policy of hegemonic power. The US has turned to international institutions when it has been to its benefit but, at the same time, it has had no qualms about distancing itself from these same institutions when it has suited its interests to do so. The shock of the 9/11 attacks led to the creation of a new security framework which was couched in terms of a no-holds-barred war - preventive if necessary against an international terrorism armed with weapons of mass destruction and backed by a series of countries that made up the "axis of evil". This policy has been expressed both through the use by the US of legal methods that allow it to control the security situation, such as legitimate defence in the case of Afghanistan, ${ }^{11}$ as well as through distancing itself from the framework for the use of force established by the UN, as in the case of the Iraq War of 2003.

\subsection{THE SOCIAL DIMENSION OF THE LEGITIMATE USE OF FORCE}

The social dimension of the legitimate use of force refers to the consent required for an action to be considered as legitimate. In order for the use of force to acquire legitimacy, it must have authorisation from the Security Council, the institution entrusted with the authority to safeguard the maintenance of international peace and security.

11. This case raises the issue of the invocation of legitimate defence against non-state actors responsible for terrorist attacks. According to Christine Gray, the implications of military action in Afghanistan for the use of force in legitimate defence can be interpreted in totally different ways. From a restrictive point of view, there would have to be a repeat of the circumstances seen in the case of Afghanistan, namely, a large-scale terrorist attack, a threat of global terrorism and a response directed against the terrorist organisation within a State providing sanctuary for its operations; the UNSC would also have to determine that the situation represented a threat to international peace and security and that the victim had the right to act in legitimate self-defence. Contrary to this vision, there is another far more worrying interpretation, which sees Operation Enduring Freedom as constituting a precedent and according to which States are free to act without recourse to the UNSC in the face of terrorist attacks against their countrymen or territory, even where there has been no proven link between the State concerned and terrorist groups. (See Gray, C. (2008) International Law and the Use of Force, Oxford: Oxford University Press, pp. 208-209.) 
As Vaughan Lowe, Adam Roberts, Jennifer Welsh and Dominik Zaum illustrate, the main sources of legitimacy for the UNSC are, on the one hand, that the aims which it seeks to protect are shared by the international community and, on the other hand, the fact that it acts in accordance with accepted principles, such as consensus, participation and cooperation. Although both elements are powerful in terms of ensuring compliance by member States, post-Cold War practices within the UNSC have highlighted tensions within the institution and have led to criticisms of double standards in its actions, selectiveness, slowness in decision-making, lack of representativeness, the political use of the right of veto, etc. (Lowe, Roberts, Welsh, and Zaum, 208, 31). This has widened the perception that the UNSC is dominated by a few countries with the right of veto who are thus in an unfair position of superiority. This vision, as David Caron argues, constitutes a challenge to the authority of the UNSC (Caron, 1993, 552-588). The UNSC has been accused of both overstretch, i.e. going beyond its functions and taking on the role of legislator, and doing too little, as in the case of the international response to disasters such as Srebrenica, Rwanda and, more recently, Darfur.

With the aim of easing these tensions, proposals have been put forward to strengthen the authority of the UNSC as the ultimate guarantor of international peace and security. The report by the Secretary-General's High-Level Panel on Threats, Challenges and Change, A More Secure World: Our Shared Responsibility, proposes changes that the UNSC will have to undergo if it is to increase its efficiency and credibility. It first proposes a series of legitimacy criteria to be taken into account by the UNSC when authorising the use of force. According to the report, the UNSC must assess the seriousness of the threat in terms of harm to the state or human security. In the case of real or imminent internal threats to the state, the UNSC must consider whether or not they meet with the defining circumstances of genocide, ethnic cleansing or serious breaches of international humanitarian law. In addition, military action must have the proper purpose, i.e. its primary purpose is to halt or avert the threat in question and be the action of last resort. Finally, the use of force must be proportional in its means, and the consequences of action not likely to be worse than those of inaction (A/59/565, para. 207). 
Secondly, the report deals with reform of the UNSC. The report acknowledges that since the end of the Cold War, in spite of fact that the UNSC has shown itself to be more than willing to act, its response has not always been as systematic and effective as would be desirable, and that this has significantly damaged its credibility (A/59/565, para. 246). The authors stress the need for the five permanent members, who have greater responsibility and therefore the greatest privileges in decision-making capacity, to more fully commit themselves to the institution and to contribute to it in a corresponding way. The reform of the UNSC must take into account a series of principles. Firstly, the reform must ensure greater participation in UNSC decision-making for those member states which contribute most in financial, military or diplomatic terms. Secondly, any reform must increase the representativeness of the body, especially with respect to developing states. And thirdly, the reforms must not compromise the efficiency of the UNSC, and they must aim to make it more democratic (A/59/565, para. 79, 249). With these principles in mind, the report proposes two models of institutional reform which divide the seats on the UNSC into four great regions: Africa, Asia Pacific, Europe and America. Model A proposes the creation of six new permanent seats and three non-permanent rotating seats of a two-year duration. According to model B, a new membership category would be created comprising eight temporary seats with a four-year duration that are renewable, as well as a new non-permanent seat with a two-year non-renewable mandate (A/59/565, para. 74-81, 251-253). Regarding the controversial right of veto, the report recognises it to be an anachronism whilst at the same time acknowledges the impossibility of eliminating it. The document includes two interesting ideas. The first is the request to the permanent members to abstain from using their right of veto in cases of genocide and serious violations of human rights. The second is a system whereby, prior to a vote being taken, the members of the UNSC would publicly indicate the way they intend to vote, even though they may actually end up voting differently when the vote actually takes place. It is thought that by exposing themselves to public scrutiny prior to voting, members would use the right to veto more responsibly (A/59/565, para. 216). 
The World Summit of 2005 provided an opportunity to adapt the UN to the world of the twenty-first century. Nevertheless, the Outcome Document of the World Summit did not include any important proposals for furthering the norms on the use of force, such as the request to not use the veto, and "it was confined to repeating the general principles established in the Charter, reaffirming the validity of the Charter and multilateralism, and reiterating the Security Council's fundamental responsibility of maintaining peace " (Andrés Sáenz de Santa María, 2008, 124).

\section{THE LEGAL, NORMATIVE AND SOCIAL DIMENSIONS OF THE LEGITIMATE USE OF FORCE IN THE DEBATES ON THE IRAQ WAR OF 2003}

This section goes on to study how the legal, normative and social dimensions that make up the complex concept of legitimacy, as put forward in this paper, are reflected in five UNSC debates on the Iraq War of 2003, one of the most controversial cases to have come before the Council in recent years, and one which saw serious internal divisions in the same. ${ }^{12}$

\subsection{THE LEGAL DIMENSION OF THE LEGITIMATE USE OF FORCE IN THE DEBATES ON THE IRAQ WAR OF 2003}

A key role in the debates was played by arguments based in international law, either to justify or reject the use of force. Those in favour of the use of force against Iraq, led by the US and the UK, focused their

12. S/PV. 4701, 5 February 2003; S/PV. 4714, 7 March 2003; S/PV. 4721, 19 March 2003; S/PV. 4726, 26 March 2003 and S/PV. 4791, 22 July 2003. 
legal arguments on the need to respond to a violation of the Iraqi government's obligations to disarm over a period of twelve years. In particular, they based their claim on the direct contravention of Resolution 1441(2002) by the Iraqi regime, which should face the "serious consequences" of its actions as set down by the resolution. ${ }^{13}$ As the UNSC meetings progressed, the discourse became firmer. Those in favour of the use of force vehemently insisted on the need to back diplomacy "with a credible threat of force" (S/PV. 4714, 28). This situation created mistrust within the UNSC, and there were mounting accusations that the leaders of the coalition aimed to resort to the automatic use of force, which those in favour of the use of force categorically denied. ${ }^{14}$

A clear and inevitable need to act comes across in all of the sessions analysed. The declarations of the coalition leaders showed a lack of patience, which was incompatible with measures other than the use of force, such as inspections. In the final meeting of the UNSC prior to the intervention, the proponents of the use of force presented a panorama in which the use of force was the only option. ${ }^{15}$ It is precisely the insistence of the representatives on the urgent need to act, to not wait any longer as the risk of hanging on could not be assumed, that has been interpreted as evidence that military power dominated the course of events. This implied a logic of impatient action that would need to be justified a posteriori and explains why, after the war, a whole system was put in place by the coalition to retroactively justify the facts that would support the military intervention (Rytovuori- Apunen, 2004, 18-49).

13. For Colin Powell, the US representative, this conclusion is "irrefutable and undeniable”. (See S/PV. 4701, p. 8). Jack Straw, the United Kingdom representative, stated that "Saddam is defying every one of us, every nation here represented. He questions our resolve and is gambling that we will lose our nerve rather than enforce our will." (See S/ PV. 4701, p.20)

14. Jack Straw responded to rumours about the willingness of the UK and the US to automatically use force, declaring "(...) the truth is that it is not being used automatically, it should not be used automatically, it will not be used automatically, and nothing to which my Government has ever put its name has ever suggested that that would be the case."(See S/PV. 4714, p. 28.)

15. The United States representative phrased it in the following way: "Under the current circumstances we have no choice but to set this work (the inspections) to one side for the time being." (See S/PV. 4721, p. 14.) 
After embarking on military action, the leaders of the coalition reaffirmed the decision they had taken, stressing that it had been an appropriate response, in line with international law, as well as being legitimate and multilateral. ${ }^{16}$ It is interesting to note that in the debates the leaders of the coalition, aside from legally justifying the intervention, insisted that it had been a multilateral action in which numerous members of the UN had participated in order to play down the accusations that they had unilaterally resorted to the use of force. ${ }^{17}$

The legal contention of the leaders of Operation Iraqi Freedom was based on the idea of the supposed authorisation of the use of force by the UNSC, that is, the authorisation of the use of force from a previous UNSC decision was presumed to be still in force. In Resolution 1441 (2002), approved unanimously by the UNSC in its $4644^{\text {th }}$ meeting on 8 November 2002, it was decided that Iraq had seriously violated its obligation to disarm (UNSC Res.1441 (2002), point 1) and that it would be granted a "final opportunity to comply with its disarmament obligations," with a tougher weapons inspection regime established in order to achieve this (UNSC Res.1441 (2002), point 2). Additionally, Iraq was warned that falsehoods, omissions or failure to comply with the duties to report on arms programmes would constitute a new serious violation of the country's obligations (UNSC Res.1441 (2002), point 4). Point 5 established the reinforced obligations for Iraq with respect to the organisations responsible for the disarmament: the United Nations Monitoring, Verification and Inspection Commission (UNMOVIC) and the International Atomic Energy Agency (IAEA).

16. Jeremy Greenstock, the UK representative, took advantage of the opportunity to clarify his commitment to international legality, stating that "any action which the United Kingdom has to take in this matter will be in accordance with international law and based on relevant resolutions of the Security Council.” (See S/PV. 4721, p. 20)

17. This was expressed by the US representative, John Negroponte, as follows: "The coalition response is legitimate and not unilateral. Resolution 687 (1991) imposed a series of obligations on Iraq that were the conditions of the ceasefire. It has long been recognized and understood that a material breach of those obligations removes the basis of the ceasefire and revives the authority to use force under Resolution 687 (1991). Resolution 1441 (2002) explicitly found Iraq in continuing material breach. In view of Iraq's additional material breaches, the basis for the existing ceasefire has been removed and the use of force is authorized under Resolution 678 (1990)" (See S/PV. 4726, p. 26.) 
Lastly, there was a warning for Iraq contained in point 13 that to continue infringing its obligations would expose the country to "serious consequences”.

Most experts in international law have concluded that the military intervention in Iraq was legally unjustifiable. The resolution to which the leaders of the coalition referred in order to justify the use of force, Resolution 687, did not contain an authorisation to enforce the Iraqi regime's compliance with its disarmament obligations "using all necessary means.” Furthermore, Resolutions 1154 and 1441, which required Iraq's compliance with its disarmament obligations, did not provide for the use of force (Conte, 2005). The fact that the UNSC gave Iraq a final chance to meet its disarmament obligations in Resolution 1441 cannot be interpreted as a green light to unilateral intervention, but rather as placing responsibility back in the hands of a strengthened inspections regime instituted by the UNSC itself. What the UNSC thus intended with these resolutions was to reserve the right to make a decision that might involve the use of force, given that it is the UNSC itself that is responsible for applying punishment in the case of the lack of respect for its resolutions (Corten, 2008, 657).

As Linos-Alexandre Sicilianos has pointed out, during the session that ended with the adoption of Resolution 1441 (2002), the members of the UNSC entered into tough negotiations to ensure that there was no trace of automaticity in the resolution. The promoters of the same, the U.S. and the UK, explained that if Iraq did not use this last opportunity then the matter would be returned to the UNSC for it to decide on the measures to be taken (S/PV.4644). As the author further points out, the fact that the leaders of the coalition promoted a new draft resolution shows that they did not envisage Resolution 1441 (2002) as providing sufficient legal basis for intervention. On February 24, 2003, the US, UK and Spain presented a draft resolution that acknowledged the failure of Iraq to comply with its disarmament obligations and that it had "failed to take the final opportunity" provided by Resolution 1441 (2002). Faced with criticism because of their attempt to obtain a blank check for the use of force, the same States presented a revised draft dat- 
ed March 7, 2003 in which Iraq was given an ultimatum to demonstrate "full, unconditional, immediate and active cooperation" in accordance with its disarmament obligations before 17 March (Sicilianos, 2009, 242 et seq.). Passage of the resolution however would require no vetoes from the council's five permanent members, which include Russia, France and China, all of which had expressed strong opposition to military action. The coalition was also well short of the requirement for nine affirmative votes, which, had they been obtained, would have enabled them to adduce that they had obtained a majority to legitimate their decision to invade. This proposed resolution was subsequently withdrawn when it became clear that a new resolution would not be passed.

As mentioned above, the debate within the UNSC was polarised between the leaders of the coalition and those members that opposed the use of force against Iraq. Those opposed to the use of force continually demonstrated their preference for using political channels, stressing that the use of force was the last resort and that they would not approve a resolution authorising the automatic use of force. Right from the first of the debates analysed here, stress was put on the importance of acting together and exercising collective responsibility in strict compliance with the UN Charter and UNSC resolutions (S/PV. 4701, 22, 26-27). Furthermore, they denied the accusations that Iraq was refusing to cooperate in the disarmament process and stressed that the peaceful channel of inspections was proving to be productive. ${ }^{18}$

One idea that the opponents of the use of force constantly stressed was that the settlement of this crisis would have important consequences in the settlement of future conflicts. There was a crucial choice to be made between the logic of force and the logic of peace, and for those opposed to the use of force, who, it should be noted, were conscious of the new climate of threats to international peace and security, it was vital to respond to the Iraq crisis within the con-

18. The French representative, Mr de Villepin, stated that "The method that we have chosen works. The information supplied by Baghdad has been verified by the inspectors and is leading to the elimination of banned ballistic equipment."(See S/PV. 4714, p. 20). 
fines of legality and to appeal to the value, function and capacity of the UN to settle current and future crises (S/PV. 4714, 18, 22).

In the final meeting prior to the start of military operations, the proponents of a peaceful solution reaffirmed their position, reiterating that the use of force could only be used as the last resort and that none of the previous UNSC decisions authorised the right to the use of force against Iraq outside the framework of the UN Charter. One of the most critical members, the French representative Mr De La Sablière, called into question the appropriateness of a preventive action to resolve "the complexity of the world." He also appealed to the responsibility of democracies to set an example by guiding their action in line with principles such as dialogue and respect for others (S/PV. 4721, 6). In this crucial moment, given the determination of the leaders of the coalition, the opponents to the use of force condemned what seemed to be the real intention behind Operation Iraqi Freedom - to overthrow the leader of a sovereign state by force - as an act that contravened the fundamental principles established in the Charter and which would have counterproductive effects for security, stability and development in the region and the rest of the world (S/PV. 4721, 8; S/PV. 4726, 28-29).

Once the military operations were under way, the criticisms became more incisive, openly judging the military operation to be illegal. The opponents to the use of force reiterated that, despite their efforts, the leaders of the coalition were not able to provide evidence of the supposed possession of weapons of mass destruction and of the relationship between the Iraqi regime and international terrorism. The accusations that Iraq constituted a threat to regional and international peace and security did thus not stand up to scrutiny (S/PV. 4726, 28).

\subsection{THE NORMATIVE DIMENSION OF THE LEGITIMATE USE OF FORCE IN THE DEBATES ON THE IRAO WAR OF 2003}

The normative dimension of the legitimate use of force is linked to the values that the norms of the international community seek to protect, that is, the maintenance of international peace and security in 
situations where they are under threat. In the debates studied here, the main threats to world security that were identified were the Iraqi regime's possession of weapons of mass destruction and its links to international terrorism. In point of fact, the first of the five UNSC sessions studied was, to a large degree, concerned with the presentation of evidence of these relations by the US Secretary of State, Colin Powell. In this context, and in line with the "war on terror", the US representative warned that, following the 9/11 attacks, he was not prepared to give Saddam Hussein the opportunity to use his weapons of mass destruction (S/PV. 4701, 19).

In the final debate prior to the commencement of military operations there was an interesting change in the line of argument related to normative issues, namely, the humanitarian twist. In this session the leaders of the coalition shifted their focus to the civilian population of Iraq. Both the United States representative, John Negroponte, and the British representative, Jeremy Greenstock, declared that their principal concern was to attend to the humanitarian needs of the Iraqi population (S/PV. 4721, 14). Calling for resentment and division within the UNSC to be put to one side, they argued in favour of priorities such as the delivery of humanitarian aid, the lifting of sanctions against Iraq, the promotion of a reconstruction programme and that the profits from trade and oil be allocated to the Iraqi people (S/PV. 4721, 20). This line of argument continued to dominate once the military intervention was under way. The leaders of the coalition emphasised that they had taken the appropriate course of action, and that it was the moment for the international community to unite in order to attend to the humanitarian needs of the Iraqi people. ${ }^{19}$

In the UNSC session on the reconstruction of the country, the leaders of the coalition stressed the advances that had been made follow-

19. The UK representative called for the UNSC to show responsibility in order for Iraq to become a country "where people can enjoy their fundamental rights without fear of oppression, and where a representative Government provides effectively for its people and manages natural resources for the exclusive benefit of all the people of Iraq." (See S/PV. 4726, p. 27-28) 
ing the intervention, such as unlimited freedom of expression and a national political body which represented the diversity of the country. Therefore, with the oppressive structure of Saddam Hussein's regime dismantled, it was the moment for the international community to cooperate in order for Iraq to achieve the conditions necessary so as to be able to determine its own future (S/PV. 4791, 31).

The normative dimension of the arguments put forward by opponents of the use of force started out from the acknowledgement of the existence of new threats such as terrorism and weapons of mass destruction. However, they criticised the illegal and preventive use of force in order to deal with these threats on the grounds that it was counterproductive (S/PV. 4714, 21). In view of the tension and division within the UNSC, the opponents to the use of force called for unity to confront this situation. ${ }^{20}$ It is interesting to note that, at the session held on the eve of the commencement of operations, the French representative referred to the importance of the capacity of being able to convince and persuade in a world in which the weak defy the strong. He stressed that action by the international community must be governed by principles such as the respect for law, the defence of liberty and justice, and a spirit of dialogue and tolerance (S/PV. 4721, 7).

As mentioned above, once the intervention had begun, the leaders of the coalition focused their reasoning on humanitarian issues. Counter to this, the opponents of the use of force responded by emphasising the sovereignty and territorial integrity of Iraq, and they condemned the manoeuvres that led to the change of the political regime through the use of force and the disastrous consequences of this. ${ }^{21}$ The UNSC members opposed to the intervention showed their willingness to contribute to the aid efforts to help the Iraqi civil popu-

20. Mr Ivanov expressed it in the following terms: "We are all standing on the same side of the barricade. We all share common values. Only by acting in solidarity will we effectively face up to new global threats and challenges."(See S/PV. 4714, p. 19.)

21. The Chinese representative, Mr Wang Yingfan, summed up these consequences as follows: "War is bound to bring about humanitarian disasters (...). War will also have a negative impact on safety, stability and development in the region and beyond." (See S/ PV. 4726, p. 29.) 
lation within the framework of the UN and EU initiatives, whilst also expressing their scepticism towards the reconstruction efforts controlled by the coalition leaders. ${ }^{22}$ For the members of the UNSC opposed to the use of force, the work of reconstruction could only be carried out by the UN due to its legitimacy, impartiality and expertise (S/PV. 4791, 16).

\subsection{THE SOCIAL DIMENSION OF THE LEGITIMATE \\ USE OF FORCE IN THE DEBATES ON THE IRAQ WAR $O F 2003$}

The social dimension of legitimacy refers to the consent required for an action to be considered legitimate, in this case, from the UNSC. The authority of the UNSC was questioned by the leaders of the coalition throughout the five debates studied. These members of the UNSC in fact warned of the risk that the UNSC was running in terms of its relevance and credibility if it continued to allow Iraq to behave in the way it was. Through the use of a powerful analogy with the League of Nations, the British representative added further pressure, stating "the League of Nations failed because it could not create actions from its words; it could not back diplomacy with a credible threat and where necessary the use of force; so small evils went unchecked, tyrants became emboldened, then greater evils were unleashed" (S/PV. 4701, 22).

The proponents of a military response stressed that UNSC members had the responsibility to make tough decisions and argued in favour of keeping up the pressure on the Iraqi regime, as otherwise it would be allowing it to continue to threaten the region and the world (S/PV. 4714, 17). Constantly emphasising their commitment to the UN, the coalition leaders presented themselves as members of the international community truly committed to the fight against threats to international security. By way of highlighting the seriousness of this commitment, both the

22. To this effect, the Chinese delegate remarked, "we are in favour of an active and effective role for the United Nations in Iraq's political process and economic reconstruction." (See S/PV. 4791, p. 14.) 
US and UK representatives referred to the tens of thousands of soldiers deployed in the zone and willing to give their lives for the UN. ${ }^{23}$

During the session prior to the military intervention, the leaders of the coalition remained firm in their position. In their discourse they transmitted the urgent need to act conclusively and they called for collective military action, urging for divisions to be left aside. ${ }^{24}$ This attitude was maintained once hostilities had got under way and the leaders of the coalition made it clear that the UNSC could not meet its responsibilities without making difficult decisions. In other words, the supporters of the use of force went about trying to impose their interpretation of the norms regarding the use of force and establishing exactly what a legitimate authority aware of the circumstances should do (S/PV. 4726, 24).

In the debate session where attention was devoted to the reconstruction of the country after the termination of the military intervention, in an attempt to legitimate their action a posteriori, the coalition leaders emphasised how the situation for Iraqis had improved and how they themselves had committed to establishing the conditions to re-establish security in Iraq "which will allow prosperity and democracy to flourish" (S/PV. 4791, 20).

With the proponents of the use of force calling into question the authority of the UNSC, the opponents stressed the need for the international community to be united in order to ensure its efficiency in responding to threats to international security. They also drew attention to the fact that UNSC decisions should be taken via deliberations involving all its members. ${ }^{25}$ Those advocating peaceful measures emphasised the legiti-

23. In the words of the UK representative: "the presence of more than 200,000 young men and women of the United States and of the United Kingdom, willing to put their lives on the line for the sake of this body, the United Nations."(See S/PV. 4714, p. 28)

24. The US representative, John Negroponte, couched it in the following terms: "Considering a work programme at this time is quite simply out of touch with the reality that we confront. (...) Under current circumstances we have no choice but to set this work (the inspections) aside for the time being."(See S/PV. 4721, p. 14)

25. As was made clear by the Chinese representative, "As for the next step to be taken, the Council should decide this through discussions among all members, based on the results of the inspections." (See S/PV. 4701, p. 20.) 
mate authority of the UNSC deriving from "all the member States of the United Nations and from all peoples of all nations" (S/PV. 4701, 23). In conjunction with this call for control of the management of the crisis to be regained by the legitimate body to do so, the mass demonstrations against the war that brought together millions of citizens around the world ${ }^{26}$ were brought up in the UNSC debate, though the only person to refer to global public opinion was the Chinese representative, who declared, "There is no reason for us to remain indifferent to these strong demands and protests" (S/PV.4714, 23).

After the intervention was under way, the UNSC members opposed to the use of force rejected the coalition's attempts to legitimate an action that was clearly illegal and to put the responsibility on the international community through the United Nations (S/PV. 4726, 29). This rejection became even more vehement in the session on the reconstruction of Iraq. For the opponents of the use of force, Iraq's sovereignty had to be re-established under the supervision of the UN, and the military occupation had to be terminated. Furthermore, although the coalition tried to justify their action by claiming that they had liberated the Iraqi people, the UNSC members against the use of force refused to take on the cost and responsibility of the country's reconstruction on the same terms as the occupying states (S/PV. 4791, 28).

As we have seen, the debate on the legitimacy of the use of force against Iraq included arguments based on the three dimensions of legitimacy. Both proponents and opponents of the use of force strove to argue and provide reasons as to the justification of their position by bringing in legal, normative and social issues. As analysis of the UNSC debates shows, in the sessions prior to the commencement of the intervention, the discourse focused on the legality of such an act. For those backing the use of force, the Iraqi regime, with its reiterated fail-

26. According to the BBC, between six and eight million protestors marched against the war in sixty countries over the weekend of 15-16 February 2003 in what were the largest demonstrations seen since the Vietnam War. According to the BBC's estimates, the world saw massive protests against the war, with $1,300,000$ protestors in Barcelona, a million in London, Rome and Baghdad, 600,000 in Madrid, 200,000 in Seville, San Francisco and Damascus, 100,000 in Sydney and New York, and 10,000 in Kolkata. See http:// news.bbc.co.uk/2/hi/europe/2765215.stm 
ure to comply with its disarmament obligations, constituted a threat to international peace and security. This legal argument was rejected by those contrary to the use of force, as it implied the automatic use of force. China, France and Russia argued in favour of the peaceful route of inspections and unleashed harsh criticisms on the postures of the coalition leaders for abandoning the unity necessary to deal with this crisis, as well as other crises in the future.

Aware that any attempt to legitimate the intervention on the basis of its legality would be vetoed when it came to the vote, the US and the United Kingdom tried a different tack. Although the suffering of the Iraqi people was mentioned in the final debate prior to the initiation of operations, it was only when the war started did the focus switch to a humanitarian threat and the arguments on weapons of mass destruction and terrorism fade into the background. The proponents of the use of force thus justified the measures taken, firstly, to liberate the Iraqi civilian population from the harm they had suffered over a long period at the hands of a cruel regime and, secondly, to show the commitment of the coalition leaders to the principles of the UN, stressing the fact that Iraqis were starting to enjoy rights and liberties that had been denied to them for decades. As Alex Bellamy maintains, the intervention of 2003 in Iraq "represents the first time that a group of intervening states have justified their actions by referring to the humanitarian outcomes produced by acts primarily motivated by non-humanitarian concerns" (Bellamy, 2004, 216-232). The opponents of the use of force responded harshly to this humanitarian twist in the line of argument. Although they recognised that the Iraqi civilian population had suffered much deprivation over a long period, China, France and Russia argued that the real aim of the coalition leaders seemed to be to change the political regime through the use of force, in direct contravention of the principle of sovereignty and territorial integrity.

Lastly, the social dimension of legitimacy was also very present in the debates studied. Whilst the US and the UK warned that if the UNSC did not act quickly and convincingly it would run the risk of losing efficiency and credibility, the opponents to the use of force claimed that the UNSC was the legitimate authority to decide and called for unity within 
the organisation, as the Iraq crisis was seen as a conflict that tested the UN's adaptive and response capacity to deal with future challenges.

\section{FINAL REMARKS}

Having studied the way in which the different dimensions of the legitimacy of the use of force appear in the UNSC debates in the foregoing sections, the intention in this final section is to reflect on the possible consequences of all this. Having analysed what was said, the task here is to analyse the role played by discourse in defining and shaping the actions taken, i.e. the potential implications of the debating process.

An initial observation, in the light of what has been set out above, is the relevance of a multi-dimensional conception of legitimacy for analysing the legitimate use of force. Study of the debates allows us to appreciate how both supporters and opponents of the use of force turned to arguments framed within the legal, normative and social dimensions of legitimacy to back up their positions. Unlike other cases, in which the permanent members of the UNSC are in agreement on the decision to make, when there is division within the UNSC the members must endeavour to justify their positions beyond their own interests (Krisch, 2008, 140-141). The key to persuading others of the legitimacy of the use of force resides in invoking lines of reasoning that are known to be accepted by the international community. As Ian Hurd argues, when all is said and done, it is the audience which accepts the legitimacy of norms "because it has been socialized to believe in these norms, it responds approvingly to actors that support them and penalizes those that do not" (Hurd, 2007a, 197).

As we have seen, the coalition leaders were very conscious of the legitimating power of UNSC authorisation and the fact that the approval of legitimate authority does make a difference. One indication of this was its determining influence in getting other member States to join the military action. Ian Hurd highlights this when he explains that states such as Turkey and Canada looked to the UNSC to signal whether it was ap- 
propriate to support the mission before defining their position (Hurd, 2007b, 197). Aside from allowing for the sharing of costs, the attempt to get UNSC authorisation also had other positive consequences, such as the qualifying of the criticisms aimed at the operation, both from national and international public opinion, as well as creating the impression that the use of force really was the last resort (Bjola, 2009, 149).

A second observation stemming from the analysis is that the action of the leaders of the coalition could be interpreted as a challenge to the norms that regulate the use of force. From the study of the lines of argument set out in the debates, it could be concluded that a new standard for interpreting the legitimate use of force was being instituted at the international level. Given the new challenges like international terrorism and weapons of mass destruction that the world is facing, according to this new interpretation the norms that regulate the maintenance of international peace and security would need to be adapted. A paradigmatic example is the United States National Security Strategy of 2002, in which it was established that the effective battle against terrorism had to be carried out with the help of friends and allies, and that this battle should be especially focused on pariah states that brutalise their own populations, aim at attaining weapons of mass destruction, sponsor terrorism, reject basic human rights and do not respect international law, in addition to being guilty of hating the US and everything that it stands for. It was also proposed that the concept of "imminent threat" be adapted to the new capabilities and aims of adversaries, as it was argued that the greater the threat, the greater the risk of inaction and, therefore, the greater the need for anticipatory self-defence, "even if uncertainty remains as to the time and place of the enemy's attack" (NSS, 2002). The Iraq War constituted the perfect time to assert this new conception of collective security.

From the UNSC debates selected for this paper we can appreciate the way in which the coalition leaders questioned the prevailing practice, in this case the appropriateness of the peaceful channel of weapons inspections under the prevailing circumstances. Furthermore, they stressed that if the UNSC was not capable of acting conclusively in the face of the Iraqi regime's repeated failure to comply with its in- 
ternational obligations, it would lose credibility and run the risk of becoming irrelevant. Put simply, if the UNSC did not adopt the coalition leaders' opinion on how the situation should be analysed and what the appropriate response was, then its authority would be seriously challenged. We can thus conclude that, through their discourse within the UNSC, the proponents of the use of force denormalised and delegitimated the system of collective security. It should be noted that every delegitimation process is coupled with a relegitimation project to establish the new interpretation of norms (Hurd, 2007a, 196). Hence the coalition leaders were seen to present themselves as the principal defenders of new norms that were adapted to the international situation, emphasising on several occasions that they did not desire war and were committed to the embodying principles of the UN. The reformulation of norms is evidently not an immediate process and is in fact difficult because it has to overcome the tendency to conserve and the resistance to change, as well as uncertainty. In order to triumph, the new model has to overcome numerous obstacles, such as inertia and habit; institutional barriers; the confusion and lack of efficiency associated with change; and the positive identification with, and favourable opinion of, the old norms on the part of some actors, amongst others (Crawford, 2002, 111).

The fact that the United States and the United Kingdom, as the leaders of the coalition formed to intervene militarily in Iraq, enacted the intervention outside of the UN system led to harsh criticism of the war as an illegitimate and illegal use of force. On the one hand, this has affected the image and prestige of the states involved, increasing the costs of unilateral political action and, on the other, it has served to reinforce the norms that regulate the use of force (Hurd, 2007a, 192). This normative framework, in spite of all its faults, has shown itself to be highly adaptable to international relations that have changed vastly over the last sixty years. In the case of the Iraq War of 2003, it was the interpretation of the legitimacy of the use of force put forward by the leaders of the coalition that was imposed. On that occasion it may have won out, but the new interpretation has certainly not succeeded in winning over everybody. 


\section{REFERENCES}

Andrés Sáenz de Santa María, P. 2008. 'Las normas relativas al uso de la fuerza: la seguridad colectiva y la legítima defensa en el contexto de la reforma de las Naciones Unidas', in García Segura, C. and Rodrigo Hernández, A.J. (eds.), La seguridad comprometida. Nuevos desafíos, amenazas y conflictos armados, Madrid: Tecnos.

- Beetham, D. 1991. The Legitimation of Power, London: Macmillan.

- Bellamy, A. 2004. 'Motives, outcomes, intent and the legitimacy of humanitarian intervention', Journal of Military Ethics, 3(3).

- Bjola, C. 2009. Legitimising the Use of Force in International Politics. Kosovo, Iraq and the ethics of intervention, London: Routledge.

- Caron, D. 1993. 'The Legitimacy of the Collective Authority of the Security Council', The American Journal of International Law, 87(4), pp. 552-588.

Cardona Llorens, J. 2003. El mantenimiento de la paz y seguridad internacionales, in Diez de Velasco, M., "Las organizaciones internacionales”, Madrid: Tecnos.

- Cardona Llorens, J. 2005. 'La "externalización”/"privatización” del uso de la fuerza por las Naciones Unidas', Soberanía del Estado y Derecho Internacional. Homenaje al Profesor Juan Antonio Carrillo Salcedo. Volume I. Universidad de Sevilla Ediciones.

- Casanovas y La Rosa, O. 2007. El principio de prohibición del uso de la fuerza, in Diez de Velasco, M., "Instituciones de Derecho Internacional Público", Madrid: Tecnos.

- Clark, I. 2005. Legitimacy in International Society, Oxford University Press.

- Conte, A. 2005. Security in the 21st Century: The United Nations, Afghanistan and Iraq. Aldershot: Ashgate. 
- Corten, O. 2008. Le droit contre la guerre. L’interdiction du recours à la force en Droit International Contemporain. Paris: Editions Pedone.

- Crawford, N. 2002. Argument and Change in World Politics. Ethics, Decolonization, and Humanitarian Intervention, Cambridge: Cambridge University Press.

- Crawford, N. 2003. 'The slippery slope to preventive war'. Ethics \& International Affairs,17 (1).

- Espósito, C. 2005. Uso de la fuerza y la responsabilidad de proteger. El debate sobre la reforma de la ONU. Informe FRIDE. http://www.fride.org/File/ViewLinkFile.aspx?FileId=680

Gray, C. 2008. International Law and the Use of Force, Oxford: Oxford University Press.

- Human Security Centre. 2005. Human Security Report 2005: War and Peace in the 21st Century. New York: Oxford University Press.

- Hurd, I. 2007a. 'Breaking and Making Norms: American Revisionism and Crises of Legitimacy', International Politics, 44.

Hurd, I. 2007b. After Anarchy. Legitimacy and Power in the United Nations Security Council, Princeton: Princeton University Press.

- Hurrell, A. 2005 'Legitimacy and the use of force: can the circle be squared?', Review of International Studies, 31, special issue.

- International Commission on Intervention and State Sovereignty. 2001. The Responsibility to Protect. http://www.iciss.ca/report-en. asp.

- Kaldor, M. 2001. Las nuevas guerras. La violencia organizada en la era global, Barcelona: Tusquets. (First publ. in English 1999)

- Kolb, R. 2003. Ius contra bellum. Le droit international relatif au maintien de la paix, Brussels: Helbing \& Lichtenhahn/Bruylant.

- Krisch, N. 2008. 'The Security Council and the Great Powers,' in Lowe, V., Roberts, A., Welsh, J., and Zaum, D., The United Nations Security Council and War. The Evolution of Thought and Practice since 1945, Oxford: Oxford University Press. 
Lagrange, P. 2004. Securité collective et exercice par le Conseil de Securité du systeme d'autorisation de la coertion. Societé Française pour le DI. Journée Francotunisienne 'Les métamorphoses de la sécurité collective. Droit, pratique et enjeux stratégiques' Hammamet (Tunisia), 24-25 June.

- Lowe, V, Roberts, A., Welsh, J. and Zaum, D. 2008 'Introduction', in Lowe, V, Roberts, A., Welsh, J. and Zaum, D. (eds.), The United Nations Security Council and War. The Evolution of Thought and Practice since 1945, Oxford: Oxford University Press.

Martín Rojo, L., Pardo M. L., and Whittaker, R. 1998. 'El análisis crítico del discurso: una mirada indisciplinada', in Martín Rojo, L. and Whittaker, R.(eds.), Poder-Decir o el poder de los discursos, Madrid: Arrecife; Ediciones de la Universidad Autónoma de Madrid.

- Ruiz-Giménez, I. 2005. La historia de la intervención humanitaria. El imperialismo altruista, Madrid: La Catarata.

- Rytovuori- Apunen, H. 2004. World Community as a Reasoned Community? A retrospective analysis of the US diplomatic persuasion on the eve of the Iraq war, in Jyrki Käkönen and Sanjay Chaturvedi (eds), 'Globalization': Spaces, Identities and (In)Securities. New Delhi: South Asian Publishers, pp. 18-49. Also published in Europe, International Almanac, Vol. IV, pp.137-158 (Tyumen, Western Siberia, September, 2004).

Sicilianos, L-A. 2009. 'Entre multilatéralisme et unilatéralisme: l'autorisation par le Conseil de Securité de recourir à la force.' Recueil des cours de l'Académie de droit international de La Haye, Leiden/Boston: Martinus Nijhoff Publishers.

- UN General Assembly. 2004. A More Secure World: Our Shared Responsibility, Report by the Secretary-General's High-Level Panel on Threats, Challenges and Change, A/59/565, 2 December 2004.

UN General Assembly. 2005. In larger freedom: towards development, security and human rights for all. Report by the Secretary-General, A/59/2005. 
- United States. White House Office. 2002. The national security strategy of the United States of America [electronic resource] President of the U.S., [Washington]: http://library.nps.navy.mil/ uhtbin/hyperion-image/nss.pdf

- Weber, M. 1944. Economía y sociedad. Fondo de Cultura Económica. (First publ. in German, 1922).

- Wheeler, N. 2000. Unilateral Humanitarian Intervention and International Law. Paper presented at the Annual Conference of the British International Studies Association, University of Bradford, 18-20 December.

- Wheeler, N. 2002. Saving Strangers. Humanitarian Intervention in International Society, Oxford: Oxford University Press. 


\section{ICIP WORKING PAPERS SUBMISSION GUIDELINES:}

\section{International Catalan Institute for Peace (ICIP)}

- The principle purpose of the ICIP is to promote a culture of peace in Catalonia as well as throughout the world, to endorse peaceful solutions and conflict resolutions and to endow Catalonia with an active role as an agent of peace and peace research. The ICIP, seeking consistency between ends and means, is governed by the principles of promoting peace, democracy, justice, equality and equity in relationships between individuals, peoples, cultures, nations and states. It holds the aim of working for human security, disarmament, the prevention and peaceful resolution of conflicts and social tensions, and strengthening the roots of peace and coexistence, peace building and advocacy of human rights.

\section{Objectives of the Publication}

- The ICIP wants to create an open forum on topics related to peace, conflict and security. It aims to open up debate and discussion on both theoretical and contemporary issues associated with the pursuit and maintenance of peace in our world. It strives to connect an eclectic group of voices including career academics, PhD students, NGO representatives, institutional representatives, and field workers and field writers to celebrate ground-breaking and constructive approaches to peace and conflict resolution.

\section{Scope of the Publication (List of Themes)}

The ICIP is interested in works related to peace, conflict and security research. It aims to provide an innovative and pluralist insight on topics of methodology of peace research, the history and development of peace research, peace education, peace-keeping and peace-creating, conflict resolution, human 
security, human rights, global security, environmental security, development studies related to peace and security, international law related to peace, democracy, justice and equality, disarmament, gender, identity and ethics related to peace, science and technology associated with peace and security.

\section{Audience:}

- The ICP aims to provide accessible, valuable and well-researched material for all those interested in the promotion of peace. Our audience includes fellow academics and researchers, student of peace ands security, field workers, institutional and governmental representatives as well as the general public.

\section{The review process}

- Peer reviewed. Submissions should be sent directly to the series editor (recerca.icip@gencat.cat), who will check whether the paper meets the formal and general criteria for a working paper and will commission a review.

- The review procedure is double-blind. The series editor will choose two anonymous reviewers, generally from the Editorial Board, but may also commission an external review from outside the ICIP.

- Reviewers are asked to write a review within a month after having received the paper. Reviews should clearly indicate one of four options: (1) accept without changes; (2) accept with minor changes; (3) allow for resubmission after major changes (4) reject. Options 2 to 4 require some detailed comments. If a paper is accepted (option 1 or 2), reviewers are kindly asked to help authors correct minor linguistic or other errors by making notes in the manuscript. If they use the track changes function for this purpose they should make sure that their comments are anonymized. 


\section{Who may submit working papers?}

- The main criterion for the submission of Working Papers is whether this text could be submitted to a good academic journal.

- ICIP staff and other fellows and visitors affiliated with the ICIP are expected to submit a working paper related to their research while at the ICIP.

\section{Submission System}

- All submissions can be made to the ICIP e-mail address: recerca.icip@gencat.cat with Working Papers - submission in the subject line.

\section{Author Biographical Statement}

- Authors must all provide a short biographical note including full name, affiliation, e-mail address, other contact information if necessary and a brief professional history. This information should be provided on a separate sheet with the title. All other personal references should be removed from the submission to ensure anonymity.

\section{Abstract}

- All papers must include English language abstracts (150 words max.)

\section{Keywords}

- A list of four to six keywords is also required.

\section{Language and Style}

- Authors may submit in Catalan, Spanish or English. The submission must be clearly written and easy to follow with headings demarcating the beginning of each section. Submission must in be Arial 11, double spaced and pages must be numbered. 
- Papers should not be longer than 15.000 words (incl. footnotes and references). Longer papers may be returned with a request to shorten them. Papers that require more extensive presentation of data may add these in an appendix that will count separately. Appendices should, however, present data in a reader-friendly and condensed format.

- Papers that will require extensive linguistic editing will not be accepted for review. Minor linguistic corrections (as well as required revisions) suggested by the reviewer must be implemented by the author before the final editing of the paper.

\section{Footnotes}

- Footnotes may be used to provide the reader with substantive information related to the topic of the paper. Footnotes will be part of the word count.

\section{References}

- The Harvard author-date system. In this system, sources are briefly cited in the text, usually in parentheses, by author's last name and date of publication. The short citations are amplified in a list of references in alphabetical list, where full bibliographic information is provided. Bibliographic references must follow The Chicago Manual of Style ( $15^{\text {th }}$ edition). See a Chicago-Style citation quick guide at:

http://www.chicagomanualofstyle.org/tools_citationguide.html Citation generators:

http://www.workscited4u.com/

http://citationmachine.net/ 
ICIP WORKING PAPERS

\section{$2010 / 8$}

Conflict, Peace and Security in Africa: an Assessment and New Questions After 50 Years of African Independence by Rafael Grasa and Oscar Mateos (available in Catalan and English)

\section{$2010 / 7$}

La OEA y la promoción de la democracia en las Américas: un objetivo en construcción by Neus Ramis

(available in Spanish and English)

\section{$2010 / 6$}

The Evolution of the Climate Change Regime: Beyond a North-South Divide? by Daniel Abreu Mejía (available in Catalan and English)

\section{$2010 / 5$}

Participation of Women in Peace Processes. The Other Tables by María Villellas

(available in Catalan, Spanish and English)

\section{$2010 / 4$}

\section{Living in the Wrong}

Neighbourhood: State Failure and its Implications for Neighbouring Countries. Cases from Liberia and Afghanistan, by Alberto Fernández Gibaja (available in Catalan and English)

\section{$2010 / 3$}

The Peace Processes in the Basque Country and Northern Ireland (1994-2006): a Comparative Approach, by Gorka Espiau Idoiaga (available in Catalan and English)

\section{$2010 / 2$}

Corte interamericana, crímenes contra la humanidad y construcción de la paz en suramérica, by Joan Sánchez (available in Spanish and English)

\section{$2010 / 1$}

Territorial Autonomy and Self-Determination Conflicts: Opportunity and Willingness Cases from Bolivia, Niger, and Thailand, by Roger Suso (available in Catalan and English)

\section{$2009 / 9$}

Lecciones de paz in Aceh: descentralización administrativa y libertad política como estrategia de pacificación in Aceh, by Javier Gil (available in Catalan, Spanish and English) 
INTERNATIONAL

CATALAN

INSTITUTE

\section{FOR PEACE}

GRAN VIA DE LES CORTS CATALANES 658, BAIXOS

08010 BARCELONA (SPAIN)

T. +34935544270| F. +34935544280

ICIP@GENCAT.CAT | WWW.ICIP.CAT 